\title{
Negotiating Islam: Conservatism, Splintered Authority and Empowerment in Urban Bangladesh
}

\section{Samia Huq}

\begin{abstract}
Bangladesh has recently been seeing a rise in religiosity which has been treated as problematic, anti-secular and anti-progressive within the public sphere. Various writers describe this trend as having a disempowering effect on women and negating their self-expression. However, underlying these views is the assumption that the assertion of women's agency is not enough if it does not confront existing structures of relations. This article asks whether it is possible that in seeking changes in certain aspects of one's life, existing gender relations are not necessarily transformed, but indirectly challenged and reconfigured? The conclusion suggests that rather than a polarisation of the secular and religious ways of living most people are in fact in between, negotiating between the two camps, and borrowing ideas and ways from both.
\end{abstract}

\section{Introduction}

In recent years, the sociopolitical climate in Bangladesh has signalled increased religiosity. This is manifested through increased veiling (Rozario 2006) by women, the proliferation of madrasas, or religious schools, (Asadullah and Chaudhury 2008) amongst the poor and faithbased schools for the middle classes, as well as the advent of Islamic media. Anthropological accounts speak of creeping conservatism (Ellickson 2004) and a preference for text-based Islam (Gardener 1998). With religious thought and practices becoming increasingly intense for many, Islam gets played out in the public sphere in problematic and often dramatic ways.

Contemporary manifestations of religion-based politics are read not only as atavistic, but part of a historical and political process that is anti-state and anti-secularism. The adoption of religious symbols in people's homes is painted with the same stroke as Islamist politics, causing secularists much anxiety. The religious and nonreligious remain polarised along ideological and political lines.

Thus, the presence of religion in the public space (whether through political groups and interests or through a woman wearing Islamic clothing and walking down the street) is seen as atavistic, regressive, anti-women and anti-empowerment. That Islam interferes with a liberal trajectory of progress and empowerment is a theme that has been captured in different kinds of writing academic, journalistic, ethnographic, as well as fictional. In Bangladesh also, there are anthropological accounts that argue that the conservatism ushered in by deepened religiosity works negatively on women's self-expression. For example, Gardener (1998) argues that the proliferation of textual Islam is leading to the seclusion of elite women and to poor women losing their avenues of self-expression. Rozario (2006) argues that conservative understandings are leading to a situation where women take on the veil. However, in spite of giving women a new sense of agency, by the demerit of not changing existing gender relations, the burqa fails to enable women to attain 'true' empowerment (Rozario 2006: 378).

Underlying such statements is the assumption that agentive self-expression does not merit gaining the status of empowerment if it does not confront existing structures of relations. Assertion of women's agency, it seems then, is not good enough if it does not attempt to transcend 
existing structures. Women's empowerment is therefore seen as part of efforts to override existing structures and assumptions, especially those related to gender relations. I ask, however: is it possible that in seeking changes in certain aspects of one's life, existing gender relations are not necessarily transformed, but indirectly challenged and reconfigured? I ask this as one of the things I found interesting about the women who attend taleem (lecture and discussion sessions organised around religious texts and explanations of how best to lead a religious life) was how they were taking strong measures within religious discourse to assert themselves, and adopt ways where questioning and critiquing of customs enabled them to reconfigure their relationships with their families and husbands without necessarily overriding norms that sanction marriage and wives' roles within it. I explore this later in the article when I discuss women who actively pursue piety. For now it suffices to say that existing accounts take a linear view of empowerment - that it entails certain processes, means certain things and yields certain outcomes, to which religious engagement that is textual and conservative is not amenable. In light of the taleem women, this article seeks to reexamine the processes of empowerment, and to argue that women who engage within religious practices and discourses also seek a certain form of empowerment which challenges certain ideals and reconfigures gender norms. It is difficult to recognise this process as such as it happens outside the parameters of those processes that have usually been seen as emblematic of empowerment. The challenge is to look at these text-based Islamic movements, and to examine the potential for empowerment that women engaged in it are seeking.

For the other two groups of women investigated for the research - factory workers and students the article argues that in engaging with religion, and having a religious worldview applied to everyday lives, women are not placed firmly on either side of the religious/secular divide. Drawing from James Wilce's kaleidophonic utterances where he demonstrates that rather than fitting into preordained categories, the Bangladeshi Muslim's identity is manifested verbally through an array of different ideas (Wilce 1998), I argue that rather than adhering to any one position, women are constantly negotiating between the religious and secular side. In order to understand the negotiation, I ask that greater attention be paid to how women's acts - even acts that seem overtly religious, or those that appear to reject religion are in fact more about the individual negotiating between different kinds of authoritative discourses. I demonstrate that a similar splintering of authority is also at play in women's narratives on rights and freedom. Given the not so insignificant place of religion in women's lives coupled with the fact that its weight is lessened by the play of other different and often conflicting discourses, I go on to ask: how does such negotiation between worldviews and discourses shed light on the way religion is seen as a controlling and disempowering effect on women's lives? I argue that women, whether they lean more on the religious or the secular side, incorporate religion into their self-expressions of agency and empowerment. I ask that we, academics and policy personnel, take this into consideration and think through ways and our own biases before leaving religious engagement out of our understanding and theorising on empowerment.

\section{Rationale for selecting the researched groups}

In order to capture the middle ground between staunch secularists and Islamists, as part of the Pathways of Women's Empowerment Research Programme Consortium (RPC), we investigated three groups of women. The first are factory workers, who have little formal education and whose significant presence in the labour force has led to changes in the economy as well as marking a change towards greater mobility and entitlements for themselves. Next, we looked at university students who by virtue of their education are expected to leave a significant mark on the socioeconomic and political landscape of Bangladesh. In addition to these two groups, we also looked at women who participate in taleem. While this latter group would fall more on the religious side of the divide than in the middle, we thought the research would have greater field-based depth and a comparative angle.

\section{The women's religious worldview}

Recent trends indicate that text-based Islam is more favourably looked upon than ever before (Ellickson 2004), and our respondents were no exception, questioning and even rejecting earlier modes of learning and understanding Islam, 
modes that include learning to read the text in Arabic without understanding it, and under the authority of elderly family members and/or a religious home-based tutor (moulobi shaheb). The factory workers, most of whom have not pursued a formal education beyond a minimal level also speak highly and favourably of 'changes in Islam' that represent textual knowledge. Shegufta said:

Our mothers and grandmothers used to believe in spirits and amulets - things that I don't much care for because I feel I know better. There are a lot of Islamic television programmes on what we should believe and how we should observe religion. I watch those and I think it gives the scope to think about my beliefs. My mother and her mother didn't have the opportunity and knowledge to think about these things as much as we do.

Safina of Gerua said:

When we were young we learnt religion from the elders in our family. There were many issues that they were not able to explain clearly. Nowadays, the hujurs [religious teachers] are educated and they study these issues in depth. I have more faith in the hujurs today.

These women's preference for a brand of Islam that is more thought through and is disseminated from extra-familial sources goes hand in hand with their affinity for taleem. The majority of the factory workers interviewed reported that taleem were held in their area, and that they have attended and enjoy attending religious meetings for women. For most women, the appeal of taleem lies in the fact that the discussions there challenge many existing norms. However, there are also women, albeit fewer, who are more comfortable with traditional sources of religious authority and knowledge. One may or may not accept the changes taleem calls for, but all unanimously agree on the respectability of the taleem apa - the woman who conducts these lessons.

University students showed very similar tendencies towards the authentication of religious beliefs and practices. Rimi of Dhaka University says:

If we want to know religion, we have to study it. I don't think we should rely on hearsay and age-old teachings. I think the media needs to be even more active in disseminating fact-based Islamic knowledge.

Farhana of Dhaka University says:
These days religion is being approached scientifically. So, education is helping us gain clarity on religion. People are now thinking about whether what we have learnt so far does or does not make sense.

Lipi commented on the extremism in faith arising out of blind faith:

There is reasoning behind what we should and should not do, and we should investigate what that reasoning is. It is good to have faith but not blind faith.

Amongst university students, while there were a handful who attend or have attended taleem, most claim that their busy schedules did not leave them enough time for it. However, those who have not participated also did not have anything negative to say about it.

In the changing religious worldview where textual knowledge is gaining ground, we see a break from the 'traditions' of the past, where dissemination of religious knowledge occurred within the home/family or through a religious teacher who was not credited with much textual knowledge. The preference for religious understanding to be something one can textually base and authenticate is an outcome of heightened levels of education, and a greater value placed on the importance of education (Eickelman 1992). Consequently, women feel more confident about cutting out the old intermediaries and relating with religion more independently, on a more one-on-one basis. In that, women also feel more in control over their own religious persuasions.

While this is a new and empowering experience for many of the women interviewed, one needs to examine the epistemology of this 'new knowledge', and assess the degree of freedom women enjoy in carving out or interpreting the texts to maximise self interest and expression. Having said that, in order to truly understand empowerment (or potential thereof) in understanding religion, one also has to consider the significance of piety or a pious disposition in circumscribing self-interest and self-expression.

\section{Women's bodies and the myth of monolithic authority}

As pointed out earlier, the preference for textbased Islam is reported to have negative consequences for women's empowerment. This 
correlation is, however, not a simplistically linear one. In order to understand the non-linear nature of the relationship between religious engagement and empowerment, I ask that we pay greater attention to the acts in which religion is called upon, and how those acts work upon the self. From women's enmeshed narratives of religion and sexuality, it is often difficult to decipher the grammar of acts, and the authorities these acts are steered by. For example, in our research we encountered a university student who used to cover her head and then gave it up. Looking at it from the outside, it is very easy to assume that she at one point felt vulnerable and/or religious and then gave it up because she had shunned that understanding of religion to embrace a more secular/liberal worldview. However, in order to get a true understanding of her act, it is important to take a closer look. She said:

I used to cover my head. But I was very uncomfortable because I was still doing 'bad' things. So, I stopped wearing it. The next time I wear it I will make sure that I am ready for it.

This quote is indicative of the view that covering should be compatible with certain ways of feeling and acting. In not covering, the women are not necessarily rejecting the religious and cultural discourses that prescribe it. Rather, they are waiting to have certain feelings, strength and emotions (if ever they do) that will enable them to refrain from undesirable acts, so that they may finally possess an interiority which will validate the act of covering. Thus, drawing on the work of Saba Mahmood, we see that the "principle of coordination between inner states and outer conducts' tells us how the self establishes variable relationships to 'structures of authority and power' (Mahmood 2005: 31). In paying closer attention to the manner in which acts that invoke religion and implicate one's sexuality, we find that women are not tightly positioned on either the religious or the secular side.

In the example about covering one's head, to be followed by taking the cover off, we see several kinds of authorities, often simultaneously, at play. First, a religious/cultural authority by which she chooses to cover her body in a particular way (through the hijab, or head cover). Next in her decision to take it off, we see an array of authorities at work: a religious understanding that dictates the ideal dispositions that accompany the hijab, and signalling to her therefore, that her current inner state does not merit wearing it. This understanding is then sanctioned by a secular authority which tells her that it is all right for her not to show her hair. Finally, her narrative hints at a future marked by uncertainty in which her final decision may be directed by either of the two sides.

The inconclusiveness or ambivalences in our understanding of the woman who chooses to take the veil may be unsettling, especially to those who are comfortably and perhaps even permanently couched in either the religious or secular camp. But the inconclusiveness is precisely what needs to be highlighted in order to argue that the tides of change also bring many doubts, and people who are caught in them are trying to make sense of the different waves differently at different times. A deeper understanding of this ambivalence is important not only for a more nuanced understanding of religious engagement, but also for greater insight into how such engagement speaks to empowerment.

What, then, are we to make of empowerment? By straddling between religious and secular discourses, are women empowered or disempowered, and to what ends? The answer to this is not a straightforward one. To take this example, in this person, there is clearly a desire to possess certain dispositions or interiorities. There is also a sense of struggle in which she can bring external acts such as donning a head cover to speak to her interiorities. The fact that she does not or cannot is spoken of as a failure by her. In that respect, she is unable to realise the full potentialities of the self in realising certain objectives, the objectives of piety in this case. Having said that, her position of negotiation or straddling allows her to put that sense of strife (and the lack of achievement) aside and live presumably with sufficient ease in a world where her lack of piety does not place logistical or other kinds of constraints on her everyday existence. In this world, the arenas upon which her life infringes (education, profession, family, etc.), and the extent to which she is able to realise her goals are not issues the research explored. I am, therefore, unable to comment on her feelings of empowerment in other spheres of her life. However, I can argue that within her worldview a 
striving for piety where her body is dealt with in a particular manner is an important issue. For a greater understanding of her sense of empowerment we would have to juxtapose her current precarious pursuit of piety (through her body) with the other aims she strives towards, and assess to what extent the two are complementary or contradictory in her notions as well as the manoeuvrings of her everyday life. Without such an analysis, it would be partial to look at her covering as an act of her submission to religion and all the patriarchal and authoritative images that this connotes. Similarly, viewing her taking off the veil as a rejection of religion and therefore a sign of greater freedom would be equally reductive. Thus, in order to understand how such women's negotiations with religion speak to empowerment, it is important that we move away from binaries, and focus instead on all the ways in which the self is applied, the ends different kinds of strife aim for, and the relationship between different aims which the self desires.

\section{Rights and freedom}

A similar splintering of authority resonates in women's articulation of rights and freedom. By rights, women refer to a variety of phenomena ranging from entitlement to property, control over their family, custody over children, the right to receive mahr (dower - that which a groom and/or his family gives to the bride), right to divorce and rights related to citizenship. The term freedom is used to explain greater mobility, the power to choose, the power to express and to vocalise thoughts and opinions. The two are inextricably linked. Thus, empowerment is overcoming structures such as marriage, family, societal stigma, etc. that have traditionally held women down in Bangladesh (Blanchet 1984; White 1992).

For both factory workers and students, freedom consists of the liberal dream, which grants them greater access to education, income, etc. Neither group considers this to be in contradiction to religious dictates. One woman said:

There is a hadith [example from the prophet's life] that asks one to treat a girl and boy equally. If a woman lives within religion, she can be absolutely free. There is nothing a woman can't do. She can do everything a man can do. She too can go to the office and to the market - she will only be helping herself by observing purdah. ${ }^{1}$ She can also have the freedom to stay home and spend time with her children.
One woman from Sylhet said:

I can't spend enough time with my children because I have to go out to work. For me this is not freedom. I would like to have the choice to stay home.

Thus, while women aspire to greater income, greater mobility and other fringe benefits, such as shopping malls, fashionable hairstyles and trendy clothing, they are also aware of a wider and more exhaustive notion of freedom. In espousing a more exhaustive freedom, we see that religion appears in two ways: through purdah, and through family.

Purdah has long been acknowledged as an important part of women's lives (Kabeer 2000). However, the importance has been assigned to the fact that it aids mobility, thereby equating purdah with strategy and rendering it devoid of any religious import. However, as indicated in the preceding section, whether it is mere instrumentality or anything beyond needs to be further investigated on the basis of what purdah means to women's lives, how they link it with not only mobility and societal acceptance, but also to their interiorities. In other words, in addition to mobility and modesty, one needs to assess how religious rhetoric facilitates in establishing a link between the act of covering and particular kinds of dispositions. One should then analyse how this link is brought to bear upon women's everyday experiences and struggles. By doing so, we would not only add greater understanding to purdah, but we would also be able to better understand its potential to offer a broader kind of empowerment.

Our research yielded more explicit statements about the relationship between family, the liberal routes to empowerment (work, income, mobility, access to commodities, etc.) and religion.

Women's statements revealed the belief that maintaining ties with the family is a cultural and a religious obligation. However, the family structures that are culturally sanctioned are not amenable to attaining what remains to be attained after she works, earns her income and buys goods for herself and her family. One woman from Bhashantek responded, 'There is no freedom after marriage, after which the husband controls everything'. Another woman said, 'I feel as though I have no rights in my life. I have to ask my husband and my-laws about everything I need and want'. 
The factory workers expressed similar feelings towards their natal families. Most of the women we spoke to who objected to being denied their inheritance, came from poor families and claimed that their natal families simply did not have enough wealth for everyone to inherit. They are aware that Islam allows them half of their brother's share, and while they think that this is unjust, they do not fight for even that. Held back again by the belief that they should foster good relations with their natal families, they barter in property rights to their brothers in lieu of a good relationship with their kin. This belief naturally does not exist in a vacuum. Women's fear of alienating their natal families arises from their lack of financial independence, education and state support.

It is easy to read women's dependence on their families as disempowering, where religious rhetoric/ideals only reinforce women's subordination. However, one also needs to take account of the fact that in Bangladesh both culture and religion stress a more family and community-based, rather than an individualistic, view of the self. In Lara Deeb's (2006) work in Lebanon, she shows that by embracing religion anew, women find great meaning in distancing themselves from a western image where a woman is portrayed as mercenary and selfishly individualistic. Rather, the self's greatest achievement lies in using the autonomy gained through employment and income to forge a relational self that not only wants to live with others, but also wants to affect religious changes in others. Thus, it is worth investigating whether the need to maintain ties with the family and the religious rhetoric that enforces this norm offers anything other than a 'way out/cop out' of structures women cannot otherwise change.

In the case of students, we see a similar understanding of the place of religion in their vision of freedom and rights. The track that most students are happy to be on is a liberal one. For students, their education and higher socioeconomic standing allowed them to speak of 'equal opportunities' at work that would engender financial betterment. They expected to be able to work in similar jobs to men, including their husbands, and be remunerated equally. As one student said, 'Freedom has everything to do with economic solvency'. Thus, for students, the liberal track is empowering, and one that needs to be pursued. However, much like the factory workers, on the liberal route to empowerment, one needs to deal with marriage and family. The women argued that marriages should be delayed, which will give women the leverage to negotiate a better standing within marriage, which they see as an essential ingredient to attaining freedom.

The women interviewed argued that while a better status within marriage is essential, this component of freedom should be sought in a delicate way, without resorting to behaviour that causes embarrassment to themselves or their families. Here, we see the same individualistic versus relational understanding of the self at play. In 'managing' religion within the liberal trajectory, women do not necessarily throw out or even object to religion. In fact, if anything, they grant religion a sanctified space, attributing injustice to society and not religion per se. For example, the same women who feel that the religio-cultural dictate that upholding the family can be a taxing job for women, are also extremely vociferous when talking about rights to mahr, or dowry, and the inheritance of property. Most of the students claimed that the lesser share portioned to women is the doing of patriarchal rules in society and not religion per se. One student said:

\section{I don't believe that Islam, with its spirit of justice would assign women less. It's our men - our husbands, fathers, brothers who don't want to give it to us. They only have to want to give us more - that would be more in line with religion.}

Thus, while liberal ideals of gender equality are very much the driving force, religion is posited as an ingredient that is compatible with the liberal trajectory. Women are making sense of religion in a manner that does not critique and shun religion, but rather enables its accommodation and appropriation into a notion of life that is empowering and just.

The taleem women have a completely inverted understanding of freedom and empowerment inverted in light of the liberal trajectory the other groups appear to be on. Their responses vary by the socioeconomic groups they belong to. The desire to have the freedom to work and be mobile varies by social positioning. While the responses vary, from not wanting to go out to going out for work and finding ways to infuse 
that with piety, the overarching issue for these women is motivation. These women's role models are iconic figures from Islamic history such as the prophet's wives, his daughter, etc., and whether a woman has to or chooses to work, they must do so because it helps them become and feel closer to God. Kinds of work and modes of comportment within it that take them away from God are to be discarded. In other words, employment and mobility have to be circumscribed within limits set by religion, where the limits take precedence over those fixed by society. Thus, we have women who have given up pursuing degrees to engage in (informal) religious learning because they believed it brought them closer to God. Similarly, there are women who have become more conscientious and meticulous at their work because they feel that that is what God expects of them, but reconfigured it by changing the dynamics of their relationship with male colleagues, or taking on the hijab. Whatever the engagement with work women have, it is second to or subsumed within the objectives set by religion.

For the taleem women, staying within the limits set by religion and being true to those limits is the source of ultimate freedom - whether that freedom is manifested through labour force participation, through housework and childrearing or through education and learning. One of the dictates advocated in taleem and believed by most participants is that rights are secondary to roles and duties. In other words, women believe that rights cannot be earned without fulfilling the duties set by God; the man's duties consist of providing for his family while the women bears and rears children and looks after the home. In this strict division of labour, there is however talk of men helping; that following the example of Prophet Muhammad, there should be no stigma attached to men helping with the housework or rearing of children. Thus, contrary to the assertion that engaging with religion does not lead to a challenge in existing gender relations, we see here that women are calling upon men to take up chores that are traditionally thought of as women's responsibility.

Women believe that an understanding of one's duties, and from it their meticulous performance will lead to optimal equilibrium at home in particular and in society in general. If each one performs their duties, and fulfils their obligations, then women inheriting half of their brothers' share will not be a burden because she will also inherit from her husband, whereas the brothers do not have rights to their wives' wealth. They believe that it is only just for a man who is answerable to God first and foremost for providing for his wife and family, to inherit more than his sister who will ideally be looked after by her husband. Thus, rights are subsumed within duties and obligations, and empowerment can only be achieved once everybody fulfils their respective duties well. This is a marked difference from the other two groups for whom rights have a much more primary position in their understanding of empowerment, where attaining rights is secondary to duties and obligations.

\section{Religious straddling and empowerment}

In this article, I have argued that in the midst of a very polarised milieu where one is considered to be staunchly secular and thereby espousing all or most liberal ideals in how one leads one's life, or succumbing to religious rhetoric, most people are in fact in between, negotiating between the two camps, and borrowing ideas and ways from both. In this negotiation, there are those, such as factory workers and students who stress outcomes that are posited and viewed as results of a liberal vision and pursuit of life. However, we see that for this group religion is not completely negated. If anything, we find that when religious rhetoric that stresses the importance of family feels burdensome, it is culture/society rather than religion that is made to shoulder the responsibility of that burden. In other words, there is a tendency to salvage religion from the disrepute of injustice and subordination, and thereby offer it a sanctified place in women's lives. While in women's everyday lives the religious may be circumscribed within the liberal, we have also seen, as exemplified through the purdah example, that everyday navigations include women making religious rhetoric speak more profoundly to the interiorities of the self.

An intensification of religious rhetoric, dictates and reasoning occurs with the taleem women, for whom religion is primary. The primary standing of religion in their lives means that all other ideas and expressions are to be circumscribed and accommodated within the religious worldview and practices. In other words, these women do not necessarily negate work, income, education, etc., but insist that such pursuits should not lead to 
compromises in religious ideas and practices. Through this, women's lives are changing and being infused with a religious ethos, where they are even appropriating certain forms. Within such appropriation, however, women continue to redefine their lives and draw a sense of power from their critique of society, family and culture and the ensuing ability to affect change in their own lives. Thus, 'empowerment' becomes intrinsically linked to religion and a life lived in accordance with religious ideals.

There has been difficulty in such religious expressions being labelled as 'empowering'. I argue that it is important we question why, and look into the stakes of giving religious selfexpression a legitimate space in academic and perhaps even policy discussions on

empowerment. First, there are the correlations of religiosity with intolerance, conflict and even violence (Hirschkind and Mahmood 2002). While these correlations are not always unfounded, we need to look at different situations and assess whether these correlations are true for every case, and the particular cultural factors and power structures that place intolerance, violence and conservative sexuality in the same box. Much probing and analytical thinking needs to take place before we discredit the appreciation for and appropriation of certain religious forms based on the assumption that they automatically accompany intolerance and violence.

Next, religious expressions such as veiling are considered to have political underpinnings. This

\section{Note}

1 The word purdah refers to various things ranging from segregation between the sexes to women's dressing that includes covering

\section{References}

Asadullah, N.M. and Chaudhury, N. (2008) 'Madrasas and NGOs: Complements or Substitutes? Non-State Providers and Growth in Female Education in Bangladesh', World Bank Policy Research Working Paper WPS4511, Washington DC: World Bank

Blanchet, T. (1984) Meanings and Rituals of Birth in Rural Bangladesh, Dhaka: University Press

Deeb, L. (2006) An Enchanted Modern: Gender and Public Piety in Shi'i Lebanon, Princeton and Oxford: Princeton University Press is a much-feared truth in Bangladesh. Academic discussions as well as popular notions tend to paint Islam in the political space and Islam in everyday lives and people's homes with the same brush, thereby preventing the latter from gaining legitimacy as a valid way of being and offering people 'real' routes to empowerment. Such links between politics and everyday experiences need to be further researched before placing empowerment derived from religion on the back burner. Finally and perhaps most importantly, as researchers we need to question our own lay, as well as academic assumptions about the link between religion and empowerment. The liberal discourse has hegemonised our minds and our intellectual endeavours to such an extent that the only space we think religion should occupy is the very private realms of people's homes and hearts. Anywhere outside of that, religion becomes a threat - not only for all of the reasons I have just mentioned, but also because it may compete with liberalism and secularism as ideals. Thus, a rethinking of our own positions, assumptions and our own discomfort with religious comportment is called for if we are to understand in the spirit of intellectual and academic objectivity where, why and how religious ideas and forms may be deemed empowering. Such an academic and selfreflective exercise will enable us to not only understand the overtly religious, but also those who are more on a liberal-secular trajectory than a religious one, but who feel that religion offers additional ways through which rights, freedom and empowerment are to be achieved.

the head to wearing a head covering plus loose clothing, and even wearing socks and gloves. Here the word refers to women's dress, notably the covering of the head.

Eickelman, D. (1992) 'Mass Higher Education and the Religious Imagination in Contemporary Arab Societies', American Ethnologist 19.4: 643-55

Ellickson, J. (2004) 'Filling the Religious Landscape in Bangladesh', Journal of Social Studies 102: 1-20

Gardener, K. (1998) 'Women and Islamic Revivalism in a Bangladeshi Community', in A. Basu and P. Jeffery (eds), Appropriating Gender, New York and London: Routledge

Hirschkind, C. and Mahmood, S. (2002) 'Feminism, the Taliban and the Politics of 
Counter-Insurgency', Anthropological Quarterly (Spring): 107-22

Kabeer, N. (2000) The Power to Choose: Bangladeshi Women Workers and Labour Market Decisions, London: Verso

Mahmood, S. (2005) The Politics of Piety: The Islamic Revival and the Feminist Subject, Princeton NJ: Princeton University Press

Rozario, S. (2006) 'The New Burqa in Bangladesh: Empowerment or Violation of
Women's Rights', Women's Studies International Forum 29.4: 368-80

White, S. (1992) Arguing with the Crocodile: Gender and Class in Bangladesh, Dhaka: University Press

Wilce, J.M. (1998) 'The Kalimah in the Kaleidophone: Ranges of Multivocality in Bangladeshi Muslim's Discourses', Ethos 26.2: 229-57 